\title{
Element analysis of the eutardigrades Richtersius coronifer and Milnesium cf. asiaticum using particle induced X-ray emission (PIXE)
}

\author{
Charlotta NILSSON,,$^{1, *}$ Ingemar JÖNSSON, ${ }^{2,3}$ Jan PALLON $^{1}$ \\ ${ }^{1}$ Division of Nuclear Physics, Department of Physics, Lund University, Box 118, SE-221 00 Lund, Sweden; ${ }^{2}$ School of Education \\ and Environment, Kristianstad University, SE-291 88 Kristianstad, Sweden; ${ }^{3}$ Department of Genetics, Microbiology \& Toxicology, \\ Stockholm University, SE-106 91 Stockholm, Sweden \\ *Corresponding author: charlotta.nilsson@nuclear.lu.se
}

\begin{abstract}
Semi-terrestrial tardigrades are well-known for their tolerance to a variety of environmental extremes, including desiccation, freezing and radiation. Despite several attempts to reveal the genetic and molecular mechanisms behind the resilience of tardigrades, it is still unknown how these animals are able to maintain the integrity of their cellular components under severe stress. Quantitative or qualitative changes in molecular compounds (e.g., carbohydrates, proteins) are expected, and have been the main line of research towards understanding the tolerance of tardigrades. In radiation tolerant bacteria, a tolerance mechanism based on manganese has been proposed. We evaluate this hypothesis in tardigrades and provide the first data on element composition in desiccated and non-desiccated specimens of two eutardigrade species, Richtersius coronifer and Milnesium cf. asiaticum. A focused $2 \mathrm{MeV}$ proton microbeam was utilised to determine the elemental content, distributions and concentrations, using the ion beam analytical technique particle induced X-ray emission (PIXE). The presence of six elements - phosphorus, sulphur, chlorine, potassium, calcium and iron-were confirmed in all tardigrade specimens, at levels up to a few $\mathrm{mg} \mathrm{g}^{-1}$. However, manganese was found in less than $10 \%$ of the analysed specimens, and in low amounts, thus our study provides no evidence for the manganese hypothesis. We also show that the distributions and/or concentrations of some elements differ between the two species as well as between the dehydrated and hydrated state. In particular, very low levels of iron were found in dehydrated M. cf. asiaticum. Our analysis shows that the PIXE technique is a useful tool for investigating questions on the distribution of elements both in dehydrated and hydrated tardigrades.
\end{abstract}

Key words: tardigrades, Richtersius coronifer, Milnesium $c f$. asiaticum, PIXE, radiation tolerance.

\section{INTRODUCTION}

Tardigrades inhabiting semi-terrestrial habitats are well-known for their tolerance to extreme environmental conditions such as desiccation, freezing, and radiation (Wright et al., 1992; Jönsson, 2003; Møbjerg et al., 2011). These abilities are shared with some species from a few other animal groups such as arthropods, nematodes and rotifers, and represent adaptations (or by-products of adaptations) to survive under very dry or cold conditions. For other organisms, exposure to these environmental stresses induces lethal damage to cells, and tardigrades must therefore possess a way to either protect their cells from damage, or efficiently repair damage that arises. Most of the early work on mechanisms of desiccation tolerance was directed towards studies on membrane stabilization molecules (Crowe et al., 1992; Crowe, 2002). More recent research has had a general molecular approach on detecting differences between animals in the desiccated (anhydrobiotic) and the hydrated states, in order to reveal the molecular and physiological mechanisms behind the tolerance (Mali et al., 2010; Reuner et al., 2010; Rizzo et al., 2010; Wełnicz et al., 2011). Although these efforts have certainly improved our knowledge on the tolerance to environmental extremes in tardigrades, we are still far from understanding the systems of protection and actual components involved. Documented tolerance to ionizing and UV radiation not only in desiccated tardigrades but also in active hydrated animals (May et al., 1964; Jönsson et al., 2005; Horikawa et al., 2006; Altiero et al., 2011) have raised the question if DNA repair mechanisms may play a role in their tolerance to radiation (Jönsson et al., 2005; Jönsson, 2007). Few studies on DNA damage and repair in tardigrades have appeared, but Neumann et al. (2009) and Rebecchi et al. (2009) reported evidence of DNA degradation after exposure to periods of anhydrobiosis, with an increase in damage with time spent in the dry state. Evidence that DNA repair mechanisms are an important part of the tolerance to desiccation and radiation in anhydrobiotic animals also comes from studies on insect larvae (Gusev et al., 2010) and rotifers (Gladyshev and Meselson, 2008).

In a study on Deinococcus radiodurans (Brooks and Murray, 1981), the most radiation tolerant organism on Earth, Daly et al. (2004) reported much higher intracellular concentration of manganese in radiation tolerant strains compared to sensitive strains. The authors suggested that radiation tolerance may rely on mechanisms 
that prevent or inactivate the damaging reactive oxygen species (ROS) that arise when radiation hits the water molecules, and that manganese performs such a role to protect the cell from ROS after irradiation. Later studies showed that also another radiation tolerant bacterium (Deinoccocus geothermalis) has high manganese/iron (Mn/Fe) accumulation (Daly et al., 2007), and that not only the levels but also the distributions of $\mathrm{Mn}$ and Fe in these two bacteria are essentially the same (Makarova et al., 2007). In these analyses, and also in a study of elemental composition of the gram-negative bacterium Pseudomonas fluorescens (Flügge) Migula, 1895 (Kemner et al., 2004), elements were determined using X-ray fluorescence analysis (XRF).

From these patterns of $\mathrm{Mn}$ and $\mathrm{Mn} / \mathrm{Fe}$ in bacteria, the hypothesis was suggested that survival following irradiation by ionizing radiation is governed by the amount of oxidative protein damage rather than by the amount of DNA damage (Daly, 2009). According to this hypothesis, high intracellular Mn:Fe ratios enable redox cycling, such that scavenging of $\mathrm{O}_{2}^{-}$(superoxide) is facilitated without producing $\mathrm{HO}$ (hydroxyl radicals) in the process. This combination of more manganese and less iron would result in less protein oxidation overall. Both $D$. radiodurans and $D$. geothermalis have $\mathrm{Mn}: \mathrm{Fe}$ ratios only slightly below 1 and survive radiation doses up to $12 \mathrm{kGy}$, as opposed to e.g. the bacterium Shewanella oneidensis, which has a $\mathrm{Mn}: \mathrm{Fe}$ ratio of only 0.0005 and survive radiation doses of only $0.07 \mathrm{kGy}$ (Daly, 2009). Thus, the key to extreme radiation tolerance could lie in simple molecular components such as manganese that protect proteins involved in repair of DNA damage, rather than in the evolution of new specific proteins.

Since tardigrades belong to the most radiation tolerant metazoans, not very far behind the bacteria in tolerated doses, it is of interest to evaluate the manganese-hypothesis of Daly (2009) in these animals. Very little is however known about the composition of chemical elements in tardigrades, or whether the element composition changes between the different states of hydration. Also in other radiation tolerant metazoans, we have found no studies on manganese levels. The purpose of this paper is therefore to evaluate if manganese-levels or distribution differ between tardigrades in the anhydrobiotic state and those in a hydrated state. The study also provides the first information on a number of other elements. In addition, we wanted to investigate possible effects of different preparation methods (freezing) of hydrated samples, as well as differences between animals with a full and an empty stomach. While the above studies in prokaryotes used Xray fluorescence to analyse elements, we have employed the ion beam analytical technique of Particle Induced Xray Emission, PIXE. To our knowledge, this is the first analysis of tardigrades using PIXE analysis.

\section{METHODS}

\section{Specimen collection}

We used the eutardigrade species Richtersius coronifer Richters, 1903 and Milnesium cf. asiaticum in our experiment, the former of which is one of the most investigated tardigrade species with respect to tolerance to environmental stress. The Milnesium population has preliminarily been identified as Milnesium asiaticum Tumanov, 2006, using the diagnostic key by Michalczyk et al. (2012a, 2012b), but until statistically satisfying morphometric data are available we prefer to classify it as $M$. cf. asiaticum. Both species were obtained from moss collected on carbonite rock fences at Öland, South-Eastern Sweden, 1-3 weeks before preparation of the experimental samples, and stored dry at room temperature. The moss was rehydrated and tardigrades extracted overnight in Baermann funnels with tap water $\left(4-4.5^{\circ} \mathrm{dH}\right)$. Extracted tardigrades were kept in refrigerator $\left(4-5^{\circ} \mathrm{C}\right)$ for $12-48 \mathrm{~h}$ until prepared for the experiment.

\section{Sample preparation}

Three types of samples with regard to treatments were used: desiccated animals, hydrated quick-frozen animals, and hydrated slow-frozen animals. The frozen samples represented active animals, and the two categories were used in order to evaluate if the rate of freezing affected the results. All samples were placed and analysed in groups of five (but individually separated) on $\mathrm{Kimfol}^{\mathrm{TM}}$ foil stretched over an acrylic glass frame before treatment (desiccation or freezing). Excess water was removed before treatment. The desiccated animal samples were prepared by placing them in a desiccator at $94.5 \%$ relative humidity and $20^{\circ} \mathrm{C}$ for 2-3 days over a saturated potassium nitrate $\left(\mathrm{KNO}_{3}\right)$ salt solution. Relative humidity was monitored by a hair hygrometer (Lambrecht GmbH, Göttingen, Germany; accuracy 2.5\% RH), inside the desiccator. In order to see if animals with food content differed in their element content from animals without food, two sets of samples with desiccated tardigrades were prepared. Hydrated slow-frozen samples were prepared by placing them in a deep freezer at $-20^{\circ} \mathrm{C}$ for approximately $3 \mathrm{~h}$, then transferred (without thawing) to an aluminium block pre-cooled in liquid nitrogen and slowly evacuated overnight (approximately $24 \mathrm{~h}$ ) in a vacuum chamber. Hydrated quick-frozen samples were frozen in liquid nitrogen $\left(-196^{\circ} \mathrm{C}\right.$, for half a minute), then kept at $-20^{\circ} \mathrm{C}$ for approximately $3 \mathrm{~h}$, before drying in a vacuum chamber as described above. Once the treatment process (desiccation or freezing) was finished, another layer of Kimfol was attached to the frame over the animals, to form a Kimfol sandwich.

After treatment and sealing of the Kimfol sandwich, all sandwiches were carbon coated, in order to minimise 
charging-up of the sample during the PIXE analysis. All in all, a total of 55 tardigrades were analysed, divided into 7 experimental groups (based on species and state), with a varying number of specimens in each group (Tab. 1). More specimens were in fact prepared - however, despite the careful carbon coating of the Kimfol sandwiches, some prepared samples still suffered from charging-up, resulting in detachment from the backing of the specimen when the proton beam approached. In particular the hydrated, quick-frozen samples suffered from detachment from the backing, leading to uneven sample sizes in different groups.

\section{Elemental analysis}

Particle induced X-ray emission (PIXE) is an ion beam analytical method, developed in the 1970s at Lund University (Johansson et al., 1970). The method employs MeV (megaelectronvolt) energy ions, produced in an accelerator, which are used to bombard the sample to be analysed. As the energetic ions hit the atoms of the sample, the ions knock out electrons in the sample atoms and create vacan- cies in inner electron shells. As these vacancies are filled by electrons from outer shells, the excess energy is emitted as characteristic X-rays, unique to the elements present in the sample. Elements heavier than sodium can be detected using this method (Johansson and Campbell, 1988), but in this study the focus was on heavier elements, e.g. Mn, at the expense of the lighter ones, i.e. in practice the lower limit was aluminum. By scanning the ion beam across the sample element maps showing the distribution of the elements in the sample can be acquired. The technique is qualitative as well as quantitative, provided that the sample matrix and the beam charge deposited is well-known. Quantitative results can also be obtained by analyzing known standards. Quantitative PIXE analysis is based on the ratio of the measured amount of X-rays to the number of irradiating protons giving rise to the corresponding characteristic X-ray peak. Sensitivity factors like cross sections for interactions, yields, absorption etc. are well-known and available in the software used for spectrum evaluation. For a thick sample, the quantitative result will be in units of mass concentration ( $\mathrm{mg} \mathrm{g}^{-1}$ or $\mu \mathrm{g} \mathrm{g}^{-1}$ ) in the volume covered by the irradiating beam. The entire experimental set-

Tab. 1. Concentrations (dry weight), including standard error of the mean, of six different elements - phosphorus, sulphur, chlorine, potassium, calcium and iron - in each of the seven experimental groups of tardigrades.

\begin{tabular}{|c|c|c|c|c|c|c|}
\hline & $\begin{array}{c}\mathrm{P} \\
\left(\mathrm{mg} \mathrm{g}^{-1}\right)\end{array}$ & $\begin{array}{c}\mathrm{S} \\
\left(\mathrm{mg} \mathrm{g}^{-1}\right)\end{array}$ & $\begin{array}{c}\mathrm{Cl} \\
\left(\mathrm{mg} \mathrm{g}^{-1}\right)\end{array}$ & $\begin{array}{c}\mathrm{K} \\
\left(\mathrm{mg} \mathrm{g}^{-1}\right)\end{array}$ & $\begin{array}{c}\mathrm{Ca} \\
\left(\mathrm{mg} \mathrm{g}^{-1}\right)\end{array}$ & $\begin{array}{c}\mathrm{Fe} \\
\left(\mathrm{mg} \mathrm{g}^{-1}\right)\end{array}$ \\
\hline $\begin{array}{l}\text { R. coronifer } \\
\text { Dehydrated } \\
\text { Full stomach } \\
\mathrm{n}=10\end{array}$ & $2.0 \pm 0.8$ & $3.4 \pm 1.3$ & $0.1 \pm 0.1$ & $1.4 \pm 0.4$ & $1.9 \pm 0.5$ & $0.1 \pm 0.1$ \\
\hline $\begin{array}{l}\text { R. coronifer } \\
\text { Dehydrated } \\
\text { Empty stomach } \\
\mathrm{n}=13\end{array}$ & $2.6 \pm 1.2$ & $4.0 \pm 1.6$ & $0.3 \pm 0.2$ & $1.6 \pm 0.3$ & $2.7 \pm 1.0$ & $0.2 \pm 0.1$ \\
\hline $\begin{array}{l}\text { R. coronifer } \\
\text { Hydrated } \\
\text { Quick-frozen } \\
\mathrm{n}=5\end{array}$ & $1.9 \pm 0.3$ & $2.0 \pm 0.3$ & $0.6 \pm 0.2$ & $1.2 \pm 0.2$ & $2.0 \pm 0.4$ & $0.3 \pm 0.05$ \\
\hline $\begin{array}{l}\text { R. coronifer } \\
\text { Hydrated } \\
\text { Slow-frozen } \\
\mathrm{n}=8\end{array}$ & $2.8 \pm 0.6$ & $3.6 \pm 0.8$ & $0.4 \pm 0.2$ & $1.5 \pm 0.3$ & $2.1 \pm 0.9$ & $0.5 \pm 0.2$ \\
\hline $\begin{array}{l}\text { M. cf. asiaticum } \\
\text { Dehydrated } \\
\mathrm{n}=7\end{array}$ & $1.6 \pm 0.4$ & $2.1 \pm 0.3$ & $0.2 \pm 0.1$ & $0.7 \pm 0.4$ & $1.9 \pm 1.0$ & $0.04 \pm 0.02$ \\
\hline $\begin{array}{l}\text { M. cf. asiaticum } \\
\text { Hydrated } \\
\text { Quick-frozen } \\
\mathrm{n}=4\end{array}$ & $2.4 \pm 0.7$ & $2.1 \pm 0.5$ & $0.6 \pm 0.2$ & $1.2 \pm 0.4$ & $4.7 \pm 1.1$ & $0.2 \pm 0.1$ \\
\hline $\begin{array}{l}\text { M. cf. asiaticum } \\
\text { Hydrated } \\
\text { Slow-frozen } \\
\mathrm{n}=8\end{array}$ & $1.6 \pm 0.7$ & $1.8 \pm 0.7$ & $0.3 \pm 0.1$ & $0.9 \pm 0.4$ & $2.6 \pm 1.2$ & $0.2 \pm 0.1$ \\
\hline
\end{tabular}


up is calibrated on a regular basis by analysing commercially available element standards that cover the periodic table. The procedure, used for a similar set-up, is found in Shariff et al. (2002).

Particle induced X-ray emission analysis was carried out on dehydrated as well as hydrated, frozen tardigrades of $R$. coronifer and $M$. cf. asiaticum. The primary scope of this study was qualitative rather than quantitative analysis, as the main focus was determination of any redistribution of elements between the hydrated and the dehydrated state, as well as differences between species. Also, the stomach content of some $R$. coronifer samples could be analysed, by comparing samples with a full stomach to samples with an empty stomach. In addition to the primarily qualitative investigation of differences between hydrated and dehydrated specimens of the same species, possible species-related differences between the two states in $R$. coronifer and $M$. cf. asiaticum were also investigated using quantitative PIXE analysis.

The PIXE analysis was carried out using $2 \mathrm{MeV}$ protons and the resulting data was analysed using the GeoPIXE software (GeoPIXE II software; http://nmp.csiro.au/GeoPIXE.html). A focused beam of approximately $15 \mu \mathrm{m}$ size was scanned over the sample, providing two-dimensional maps showing element distributions across the sample. Samples were analysed using a proton current of about $250 \mathrm{pA}$ and the analysis time per sample was typically around 40 minutes. The detector used was an 8 element Canberra HPGe detector (Shariff et al., 2004), equipped with a $25 \mu \mathrm{m}$ thick Mylar absorber. To achieve data for quantitative analysis, beam current and analysis time was monitored and beam charge was measured in a Faraday cup before the sample. In addition, a Ti standard (Micromatter ${ }^{\mathrm{TM}}$, Vancouver, Canada) was also analysed, to be able to normalize against this standard in GeoPIXE. The sample matrix, needed for the X-ray yield calculation and absorption correction, was chosen as chitin, $\mathrm{C}_{8} \mathrm{H}_{13} \mathrm{O}_{5} \mathrm{~N}$, with a density of $1 \mathrm{~g} \mathrm{~cm}^{-3}$. From the elemental map, a region of interest is chosen, which completely covers the animal. The data is merged into a spectrum which represents the whole animal. When quantifying a thin sample the results represent mass per unit area, and for a thick sample the results represent ppm or $\mu \mathrm{g}$ $\mathrm{g}^{-1}$. For additional information, see Johansson and Campbell (1988).

For the results reported here, the values represent averages of elemental concentrations taken from the whole tardigrade and referring to dry weight. As seen in Figs. 1-4, there are strong local variations of elemental concentrations; the signals shown here were normalised for each element and given as relative values.
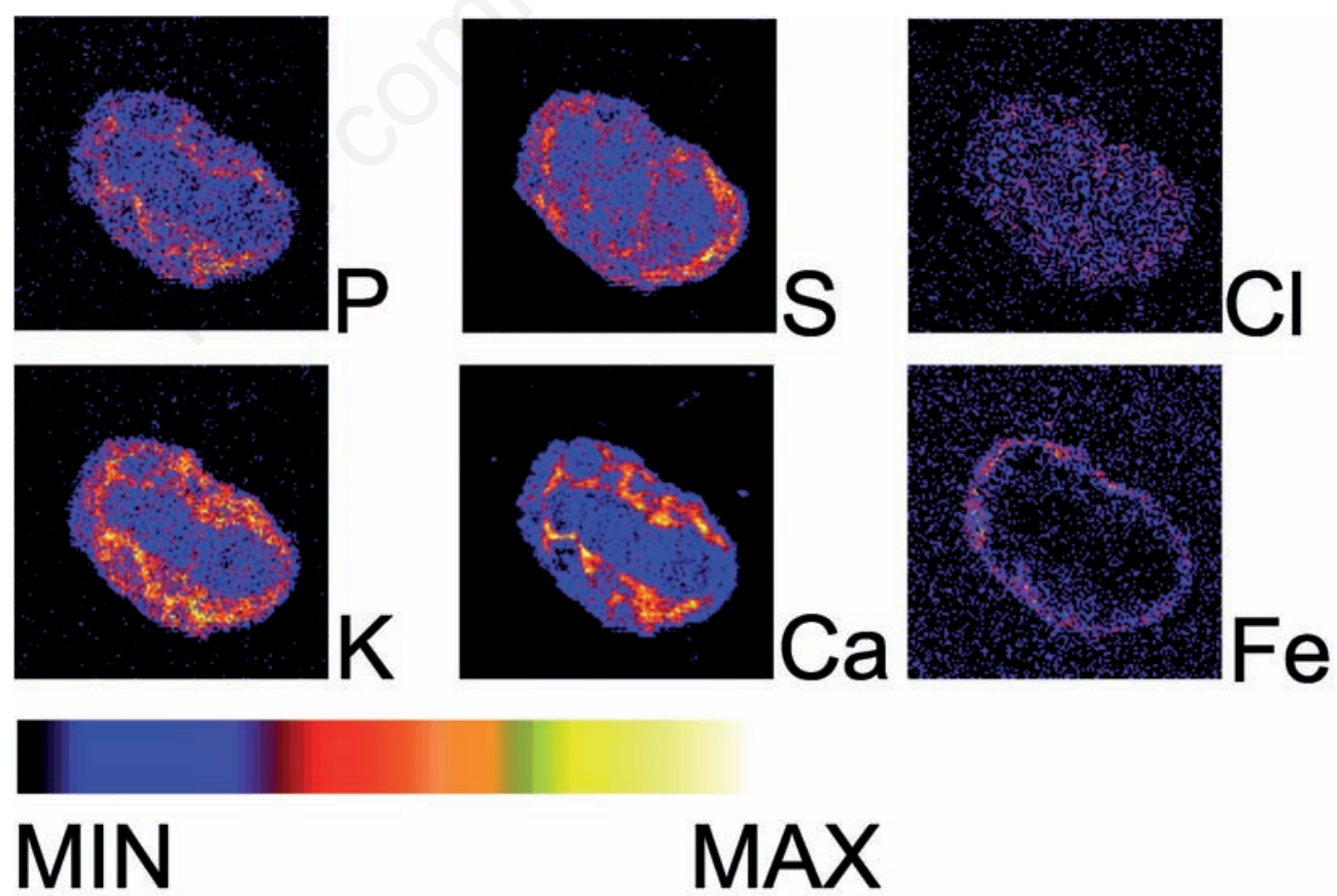

Fig. 1. Particle induced X-ray emission images showing the distribution of phosphorus, sulphur, chlorine, potassium, calcium and iron in desiccated $R$. coronifer, with an empty stomach. 


\section{Statistical analysis}

Differences in the element concentration between i) the two species, ii) hydrated and dehydrated specimens of the same species, iii) quick- and slow-frozen hydrated specimens of the same species, and finally iv) dehydrated $R$. coronifer with full and empty stomach were tested using Analysis of Variance, one-way ANOVA (SYSTAT 12 , SYSTAT Software Inc.), with $P>0.05$ considered nonsignificant and $\mathrm{P}<0.05$ as significant. The Shapiro-Wilk test was used to test the data for normality distribution.

\section{RESULTS}

\section{Qualitative elemental analysis of tardigrades}

Figs. 1-4 show some representative elemental maps of a dehydrated and a hydrated, quick-frozen tardigrade of each of the two analysed species. All maps are 384 $\mu \mathrm{m} \times 384 \mu \mathrm{m}$ in size. Significant levels of phosphorus, sulphur, potassium and calcium are present in both states and in both species. The levels of iron and chlorine are low, but the elements are found in all samples, irrespective of species and state. In contrast, the distribution of chlorine is different between the two states. In the hydrated animals, chlorine is to a higher extent found along the outer edge of the body, whereas in the dehydrated animals, chlorine is more evenly distributed in the body. Iron also appears to be differently distributed between the states, as there appears to be cavities in the dehydrated tardigrades, where this element is not found. A similar cavity pattern is seen in the calcium maps and to a certain extent in the phosphorus maps. Moreover it can be seen that, at least in the $M$. cf. asiaticum specimens, the elements calcium and phosphorus overlap nicely, as do sulphur and potassium and potassium and chlorine as well (Figs. 3 and 4).

The presence of manganese in these tardigrade specimens could only be confirmed in five out of 55 samples (both $R$. coronifer and $M$. cf. asiaticum were represented) and in all five cases, the levels were very low - 0.01-0.02 $\mathrm{mg} \mathrm{g}^{-1}$. In the rest of the samples, the manganese level was below the detection limit $\left(0.01 \mu \mathrm{g} \mathrm{g}^{-1}\right)$, which means that the presence of lower levels of manganese in tardigrades cannot be excluded. Thus, no elemental maps of manganese are presented in this paper. Calcium is known to be a component of the buccal-pharyngeal structures of tardigrades, and particularly of the stylet (Bird and McClure, 1997; Guidetti et al., 2012). This was also confirmed in our analyses, where the stylet was the most clearly visible structure of the buccal-pharyngeal apparatus. Also in line with the study by Guidetti et al. (2012), the presence of calcium was much more prominent in the stylets of $R$. coronifer compared to $M$. cf. asiaticum with strong signals (as in Fig. 2) in about 55\% of the R. coro-
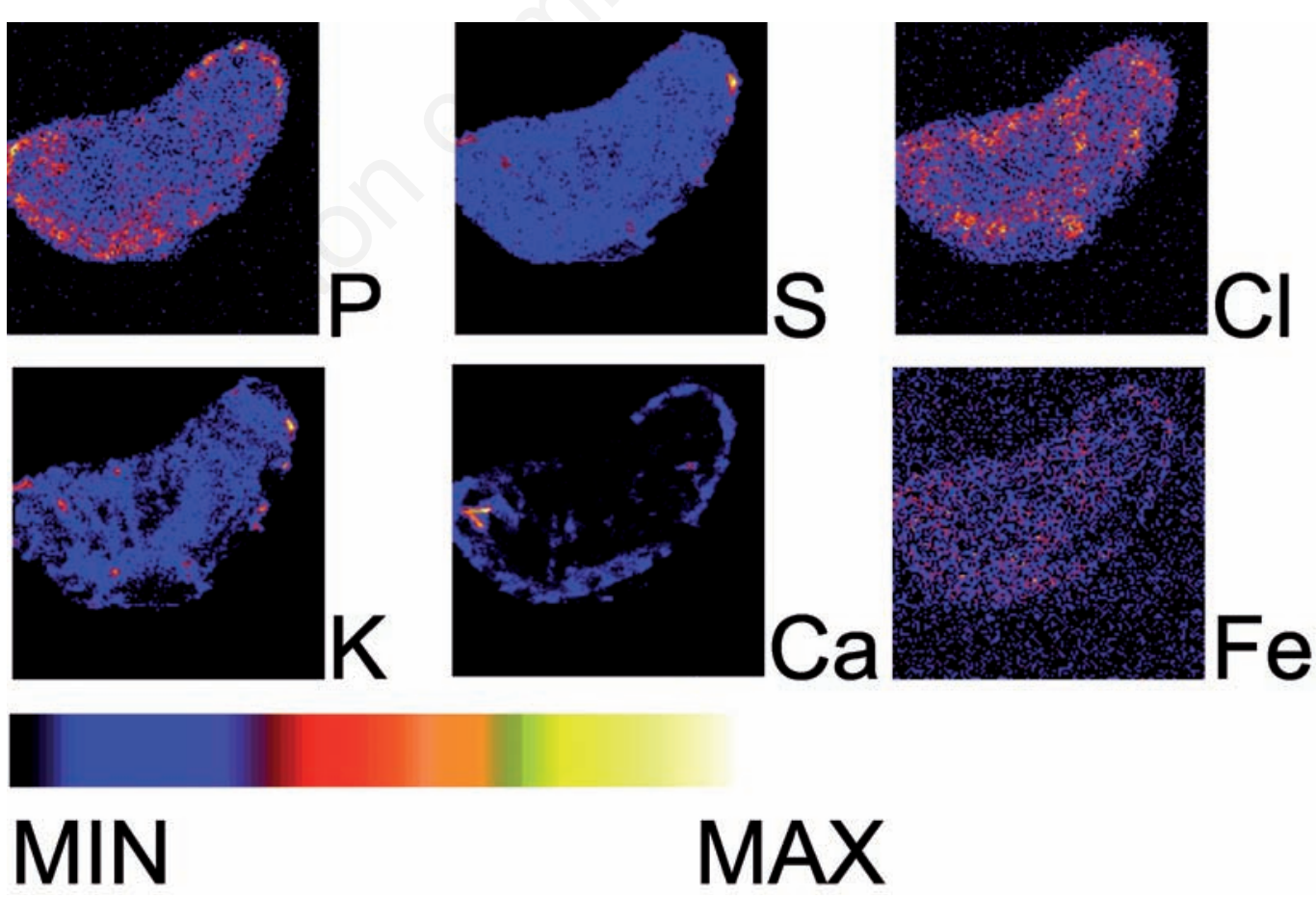

Fig. 2. Particle induced X-ray emission images showing the distribution of phosphorus, sulphur, chlorine, potassium, calcium and iron in hydrated, quick-frozen $R$. coronifer. 
nifer specimens. Only about $25 \%$ of the Milnesium specimens showed clear signs of the stylets, and then mainly in the piercing part of the stylet, as also shown by Guidetti et al. (2012). Why the stylet was not clearly visible in calcium maps of all $R$. coronifer specimens is unclear, but in some cases the animal may have been in the simplex stage connected with moulting, during which the stylet and buccal tube is absent and the animal is not feeding. The presence of simplex stages was not checked in the used specimens, but $R$. coronifer in the empty stomach category had a considerably lower percentage of visible stylets $(23 \%)$ than the average, which indicates that many of those specimens may have been in simplex stage. In a few specimens of both $R$. coronifer and Milnesium calcium was also indicated in assumed areas of the claws.

\section{Quantitative elemental analysis of tardigrades}

Tab. 1 gives the mean concentration (in $\mathrm{mg} \mathrm{g}^{-1}$ ) and standard error of the mean for the six elements phosphorous, sulphur, chlorine, potassium, calcium and iron. One should keep in mind that these values describe the average content across the whole animal, not taking into account the fact that the concentration varies in the body of the tardigrade, as can be seen from the figures in the previous section. Roughly half (25) of the samples were found to contain very low, but measureable levels of copper (mean value $\left.=0.08 \mathrm{mg} \mathrm{g}^{-1}\right)$ and all but nine of the samples contained zinc (mean value $=0.2 \mathrm{mg} \mathrm{g}^{-1}$ ) as well. Comparing all seven experimental groups, we found significant differences among groups for sulfur, chlorine, potassium, calcium, iron and phosphorus $(\mathrm{S}, \mathrm{Cl}, \mathrm{K}, \mathrm{Ca}, \mathrm{Fe}$ and $\mathrm{P}$, respectively) $(\mathrm{P}=0.000$ in all cases except for element $\mathrm{P}$, where $\mathrm{P}=0.022$ ). Significant and marginally significant results from pairwise comparisons are shown in Tab. 2.

\section{Slow- versus quick-frozen hydrated samples}

Comparing slow- and quick-frozen $R$. coronifer, we found significant differences for elements $\mathrm{S}, \mathrm{Cl}$ and $\mathrm{Fe}$, with higher levels of $\mathrm{S}$ and $\mathrm{Fe}$ in the slow-frozen group, and higher levels of $\mathrm{Cl}$ in the quick-frozen group. In $M$. cf. asiaticum an opposite but non-significant pattern was observed for $\mathrm{P}$ and $\mathrm{S}$, while levels of $\mathrm{Cl}$ and $\mathrm{Ca}$ were significantly higher in the quick-frozen group. These results indicate that the method of freezing influences the measurement of some elements. Whether these differences represent adaptive physiological adjustments taking place in the body of the slow-frozen tardigrades, or is due to some physical reason related to the freezing rate is unclear, but in our comparisons between hydrated and dehydrated tardigrades we have analysed slow-frozen and quick-frozen tardigrades separately.
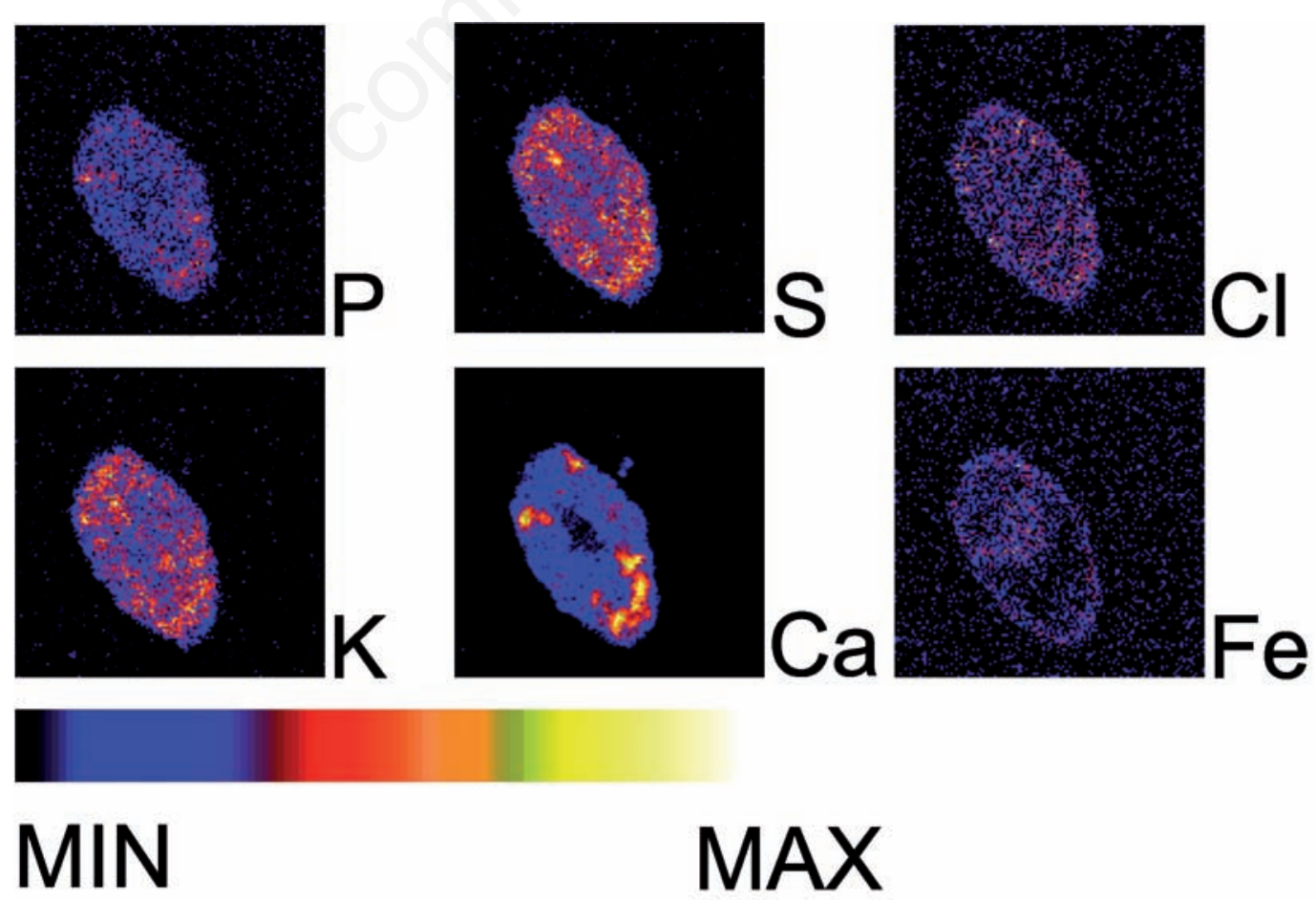

Fig. 3. Particle induced X-ray emission images showing the distribution of phosphorus, sulphur, chlorine, potassium, calcium and iron in desiccated $M$. cf. asiaticum. 


\section{Dehydrated versus frozen hydrated samples}

Comparing dehydrated versus quick-frozen $M$. cf. asiaticum we found significant differences for $\mathrm{Cl}, \mathrm{Ca}$ and $\mathrm{Fe}$. In all cases, lower levels were found in the dry samples. For dehydrated versus slow-frozen $M$. cf. asiaticum, only Fe showed a significant difference between groups, with five times higher levels in the frozen samples.

In $R$. coronifer, significant differences between dehydrated (similar outcome independent on whether samples had stomach content or not) and quick-frozen samples were found for $\mathrm{Cl}$ and $\mathrm{S}$, with dehydrated samples having higher levels of $\mathrm{S}$ and lower levels of $\mathrm{Cl}$. Comparing dehydrated versus slow-frozen $R$. coronifer, only one difference, common to both full and empty stomach, was found - a significantly lower level of Fe in the dehydrated samples. In addition, a significantly lower level of $\mathrm{Cl}$ in the dehydrated samples with full stomach was also found.

\section{Full stomach versus empty stomach in $R$. coronifer}

Dehydrated $R$. coronifer with and without stomach content showed significant differences in element levels only for $\mathrm{Cl}$ and $\mathrm{Ca}$ (Tab. 2) and in both cases element levels were higher in the animals with empty stomach.

\section{Richtersius coronifer versus $M$. cf. asiaticum}

Including all dehydrated samples, we found significant differences in elements $\mathrm{S}$ and $\mathrm{K}$ levels between $R$. coronifer and $M$. cf. asiaticum. Dehydrated $M$. cf. asiaticum had in both cases lower levels than $R$. coronifer. A more pronounced difference was found between $R$. coronifer with empty stomach and $M$. cf. asiaticum, with significant differences also in $\mathrm{P}, \mathrm{Cl}$ and $\mathrm{Fe}$ - in all cases higher levels in $R$. coronifer. For quick-frozen samples, a significant difference between $R$. coronifer and $M$. cf. asiaticum was found for $\mathrm{Ca}$ only, where $M$. cf. asiaticum had on average more than twice the levels of $R$. coronifer. For slow-frozen samples, however, there were more significant differences between the species in levels of $\mathrm{P}, \mathrm{S}, \mathrm{K}$ and Fe, and in all cases $R$. coronifer had higher levels than $M$. cf. asiaticum.

\section{DISCUSSION}

Our analysis did not provide any support for the manganese hypothesis proposed by Daly et al. (2004, 2007), a hypothesis which suggests that manganese plays a role in tolerance to desiccation and radiation by preventing the action of damaging reactive oxygen species. The two tardigrade species investigated had very low levels of
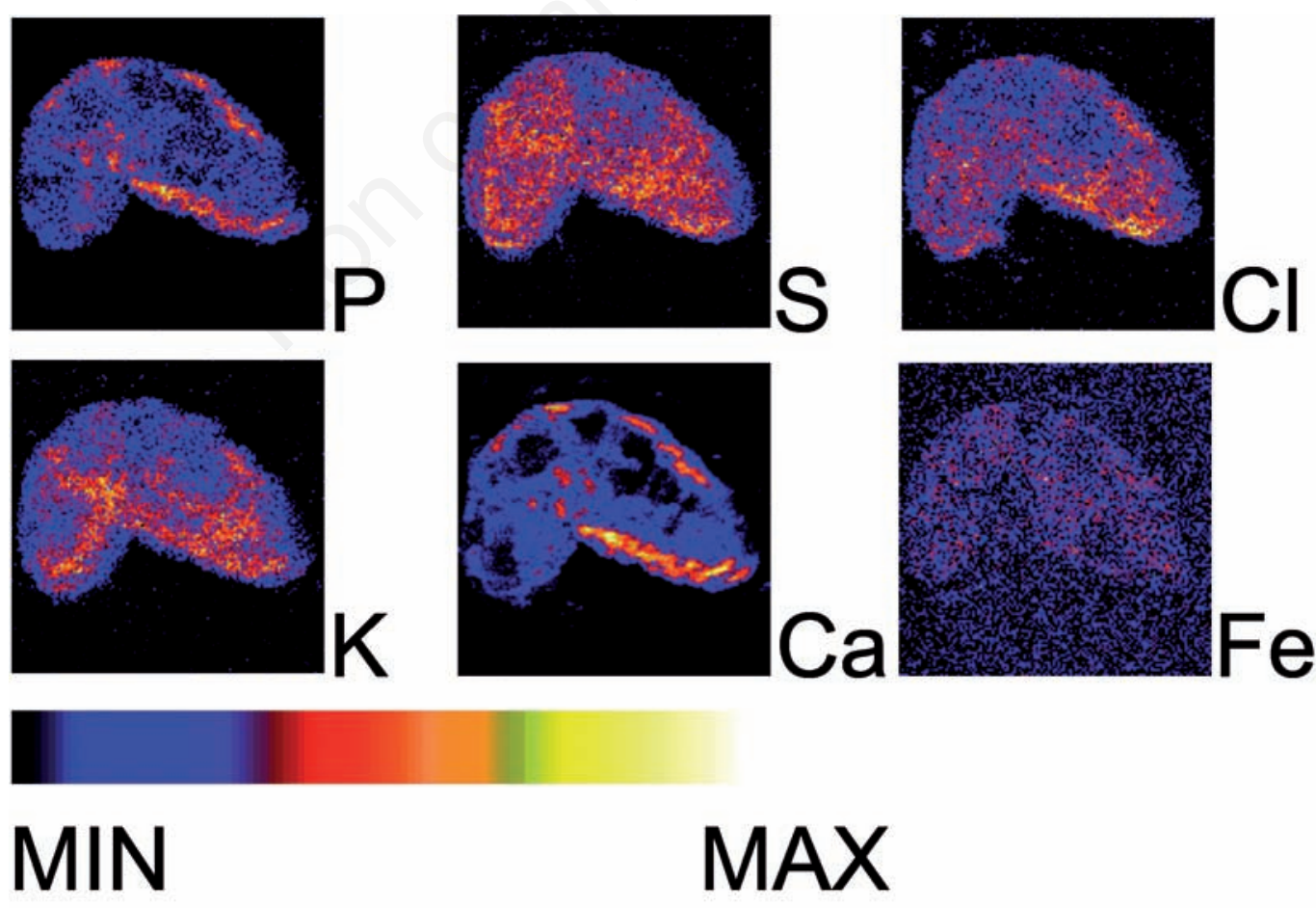

Fig. 4. Particle induced X-ray emission images showing the distribution of phosphorus, sulphur, chlorine, potassium, calcium and iron in hydrated, quick-frozen M. cf. asiaticum. 
manganese, and the element was only found in a minority of specimens. The levels of iron were considerably higher, resulting in a $\mathrm{Mn}: \mathrm{Fe}$ ratio well below 0.1 . Thus, from this investigation it seems clear that manganese, or the $\mathrm{Mn}: \mathrm{Fe}$ ratio, is not involved in the radiation and desiccation tolerance of tardigrades, as suggested for bacteria.

No studies on tolerance have been done in $M$. cf. asiaticum, but another species (reported as Milnesium tardigradum Doyère 1840 but probably also $M$. asiaticum or $M$. cf. asiaticum) has been reported to be more tolerant than $R$. coronifer to ultraviolet radiation, freezing, and high temperature (Ramløv and Westh, 1992, 2001; Jönsson et al., 2008; Hengherr et al., 2009a, 2009b). Also differences in biochemistry connected with desiccation have been documented in these two species (Westh and Ramløv, 1991; Hengherr et al., 2008; Jönsson and Persson, 2010). One of the differences in element content between $M$. cf. asiaticum and $R$. coronifer in our study was a clearly lower level of iron in dehydrated $M$. cf. asiaticum. This level contrasted also against the hydrated specimens of the same species, indicating a possible involvement of this element in the biochemical adjustment to the dry state. Also in $R$. coronifer, dehydrated specimens had lower levels of iron than hydrated specimens. Further studies are obviously of interest to reveal why both tardigrade species, and $M$. cf. asiaticum in particular, show such low levels of iron in the dehydrated state. For several other elements, $M$. cf. asiaticum had lower values than $R$. coronifer. The reason for this is hard to explain, but our results may be used to generate ideas and hypotheses about differences in physiology between the two species. The same holds for the qualitative results, where some differences in distribution were found, e.g., in the distribution of iron, chlorine and calcium.

The reason for the differences found between slowand quick-frozen samples is currently unclear, but one possibility is that our slow-freezing method allowed the animals to prepare their bodies biochemically for a dry state. If so, they should be more similar in their element levels to the dehydrated samples than to the quick-frozen

Tab. 2. Statistical significances (P values) from pair-wise post-hoc ANOVA comparisons of element amounts (see Tab. 1) among experimental groups, using Fisher's least-significant-difference test. Element name is given as subscript. Marginally significant results are given in parentheses.

\begin{tabular}{|c|c|c|c|c|c|c|c|}
\hline & $\begin{array}{c}\text { R. cor. } \\
\text { Dehyd. FS }\end{array}$ & $\begin{array}{c}\text { R. cor. } \\
\text { Dehyd. ES }\end{array}$ & $\begin{array}{l}\text { R. cor. } \\
\text { QF }\end{array}$ & $\begin{array}{l}\text { R. cor. } \\
\text { SF }\end{array}$ & $\begin{array}{l}\text { M. cf. asiaticum. } \\
\text { Dehyd. }\end{array}$ & $\begin{array}{c}\text { M. cf. asiaticum } \\
\text { QF }\end{array}$ & $\begin{array}{c}\text { M. cf. asiaticum } \\
\text { SF }\end{array}$ \\
\hline $\begin{array}{l}\text { R. coronifer } \\
\text { Dehydrated } \\
\text { FS }\end{array}$ & - & $\begin{array}{l}\mathrm{P}_{\mathrm{Cl}}=0.004 \\
\mathrm{P}_{\mathrm{Ca}}=0.046 \\
\left(\mathrm{P}_{\mathrm{P}}=0.065\right)\end{array}$ & $\begin{array}{c}\mathrm{P}_{\mathrm{s}}=0.018 \\
\mathrm{P}_{\mathrm{Cl}}=0.000 \\
\left(\mathrm{P}_{\mathrm{Fe}}=0.055\right)\end{array}$ & $\begin{array}{l}\mathrm{P}_{\mathrm{Fe}}=0.000 \\
\mathrm{P}_{\mathrm{Cl}}=0.006 \\
\left(\mathrm{P}_{\mathrm{P}}=0.051\right)\end{array}$ & $\begin{array}{l}\mathrm{P}_{\mathrm{s}}=0.014 \\
\mathrm{P}_{\mathrm{K}}=0.001\end{array}$ & $\begin{array}{l}\mathrm{P}_{\mathrm{s}}=0.040 \\
\mathrm{P}_{\mathrm{Cl}}=0.000 \\
\mathrm{P}_{\mathrm{Ca}}=0.000\end{array}$ & $\begin{array}{c}\mathrm{P}_{\mathrm{s}}=0.003 \\
\mathrm{P}_{\mathrm{K}}=0.006 \\
\left(\mathrm{P}_{\mathrm{Ca}}=0.097\right)\end{array}$ \\
\hline $\begin{array}{l}\text { R. coronifer } \\
\text { Dehydrated } \\
\text { ES }\end{array}$ & - & - & $\begin{array}{l}\mathrm{P}_{\mathrm{s}}=0.001 \\
\mathrm{P}_{\mathrm{Cl}}=0.001 \\
\mathrm{P}_{\mathrm{K}}=0.037\end{array}$ & $\mathrm{P}_{\mathrm{Fe}}=0.000$ & $\begin{array}{c}\mathrm{P}_{\mathrm{s}}=0.001 \\
\mathrm{P}_{\mathrm{P}}=0.010 \\
\mathrm{P}_{\mathrm{C}}=0.023 \\
\mathrm{P}_{\mathrm{K}}=0.000 \\
\mathrm{P}_{\mathrm{Fe}}=0.025 \\
\left(\mathrm{P}_{\mathrm{Ca}}=0.090\right)\end{array}$ & $\begin{array}{c}\mathrm{P}_{\mathrm{s}}=0.004 \\
\mathrm{P}_{\mathrm{Cl}}=0.011 \\
\mathrm{P}_{\mathrm{Ca}}=0.000 \\
\left(\mathrm{P}_{\mathrm{K}}=0.066\right)\end{array}$ & $\begin{array}{l}\mathrm{P}_{\mathrm{s}}=0.000 \\
\mathrm{P}_{\mathrm{K}}=0.000 \\
\mathrm{P}_{\mathrm{P}}=0.009\end{array}$ \\
\hline $\begin{array}{l}\text { R. coronifer } \\
\text { QF }\end{array}$ & - & - & - & $\begin{array}{c}\left(\mathrm{P}_{\mathrm{P}}=0.076\right) \\
\mathrm{P}_{\mathrm{s}}=0.010 \\
\mathrm{P}_{\mathrm{Cl}}=0.003 \\
\left(\mathrm{P}_{\mathrm{K}}=0.091\right) \\
\mathrm{P}_{\mathrm{Fe}}=0.002\end{array}$ & $\begin{array}{l}\mathrm{P}_{\mathrm{Fe}}=0.004 \\
\mathrm{P}_{\mathrm{Cl}}=0.000 \\
\mathrm{P}_{\mathrm{K}}=0.048\end{array}$ & $\mathrm{P}_{\mathrm{Ca}}=0.000$ & $\mathrm{P}_{\mathrm{Cl}}=0.000$ \\
\hline $\begin{array}{l}\text { R. coronifer } \\
\text { SF }\end{array}$ & - & - & - & - & $\begin{array}{l}\mathrm{P}_{\mathrm{P}}=0.009 \\
\mathrm{P}_{\mathrm{s}}=0.008 \\
\mathrm{P}_{\mathrm{Cl}}=0.026 \\
\mathrm{P}_{\mathrm{Fe}}=0.000 \\
\mathrm{P}_{\mathrm{K}}=0.000\end{array}$ & $\begin{array}{l}\mathrm{P}_{\mathrm{s}}=0.024 \\
\mathrm{P}_{\mathrm{Cl}}=0.024 \\
\mathrm{P}_{\mathrm{Ca}}=0.000 \\
\mathrm{P}_{\mathrm{Fe}}=0.001\end{array}$ & $\begin{array}{l}\mathrm{P}_{\mathrm{s}}=0.001 \\
\mathrm{P}_{\mathrm{P}}=0.008 \\
\mathrm{P}_{\mathrm{K}}=0.001 \\
\mathrm{P}_{\mathrm{Fe}}=0.000\end{array}$ \\
\hline $\begin{array}{l}\text { M. cf. asiaticum } \\
\text { Dehydrated }\end{array}$ & - & - & - & - & - & $\begin{array}{l}\left(\mathrm{P}_{\mathrm{K}}=0.053\right) \\
\mathrm{P}_{\mathrm{Ca}}=0.000 \\
\mathrm{P}_{\mathrm{Cl}}=0.000 \\
\mathrm{P}_{\mathrm{Fe}}=0.024\end{array}$ & $\mathrm{P}_{\mathrm{Fe}}=0.035$ \\
\hline $\begin{array}{l}\text { M. cf. asiaticum } \\
\text { QF }\end{array}$ & - & - & - & - & - & - & $\begin{array}{l}\mathrm{P}_{\mathrm{Cl}}=0.002 \\
\mathrm{P}_{\mathrm{Ca}}=0.001\end{array}$ \\
\hline $\begin{array}{l}\text { M. cf. asiaticum } \\
\text { SF }\end{array}$ & - & - & - & - & - & - & - \\
\hline
\end{tabular}


hydrated samples. This tends to be the case, since in both tardigrade species we found more significant differences in element levels between dehydrated and quick-frozen samples (M. cf. asiaticum: $\mathrm{Cl}, \mathrm{Ca}, \mathrm{Fe} ; R$. coronifer: $\mathrm{Cl}, \mathrm{S}$ ) than between dehydrated and slow-frozen samples (both species: Fe). Thus, when freezing of tardigrades is used to get specimens representing hydrated states, utilization of rapid freezing media such as liquid nitrogen is essential. However, it should be remembered that in analyses of the distribution of elements in the body, and perhaps also in quantitative analyses, rapid freezing may give rise to structural changes or damage induced by the freezing treatment that lead to a different distribution of elements compared to specimens treated in other ways.

A challenge in analysing whole tardigrades is that we cannot distinguish at what depth the X-rays originate. We know, from the data analysis software GeoPIXE (GeoPIXE II), that for the lightest elements in our analysis, e.g. phosphorus, we get $90 \%$ of the information about the element content ( $90 \%$ of the X-ray yield) in the first $40 \mu \mathrm{m}$ of the sample, whereas for the heavier elements of our analysis, e.g. potassium and iron, we get $90 \%$ of the information in the first $80 \mu \mathrm{m}$ of the sample. Thus, the thickness of the tardigrades and the random orientation of them on the backing may influence the results more in the case of the lightest elements in our analysis. The maximum thickness of dehydrated tardigrades has been found to exceed $150 \mu \mathrm{m}$ (Nilsson et al., 2010), but frozen tardigrades are thinner. Thus, especially in the case of the lightest elements, we have in our present analysis not been able to probe the center of the samples. We plan to overcome this in future studies by analyzing sectioned tardigrades. Analyzing thin slices (of the same thickness) will give us the opportunity to obtain an improved quantification as well as resolution, which in turn would better correlate the element maps to structures in the tardigrade. Another option would be a micro-tomographical analysis. To get an indication if sample orientation may have effects on estimated element levels, one of our tardigrade samples was analysed twice, turning the sample back to front between the two analyses. The results for our six main elements (data not shown) did not indicate any obvious differences in the quantification due to orientation of the specimen, but as this comparison was based on one specimen only we cannot draw any firm conclusions.

\section{CONCLUSIONS}

Despite the methodological issues discussed above, our elemental analysis shows that PIXE is a suitable method for determining the element content in both hydrated and dehydrated tardigrades, with high spatial resolution. Even better results should be acquired if sectioning the tardigrades before analysis. Thus, this method can be used to evaluate specific hypotheses about redistribution of elements in connection with dehydration, and the role of different elements in tolerance to dehydration and radiation.

\section{ACKNOWLEDGMENTS}

We are grateful to J. Genberg for valuable input regarding the statistical analysis, and to referees for valuable comments. Financial support from The Gyllenstierna Krapperup's Foundation (to E.J.C. Nilsson), and the Swedish Space Agency (to K.I. Jönsson) is gratefully acknowledged.

\section{REFERENCES}

Altiero T, Guidetti R, Caselli V, Cesari M, Rebecchi L, 2010. Ultraviolet radiation tolerance in hydrated and desiccated eutardigrades. J. Zool. Syst. Evol. Res. 49(Suppl. 1):104110.

Bird AF, McClure SG, 1997. Composition of the stylets of the tardigrade, Macrobiotus cf. pseudohufelandi. Trans. Roy. Soc. South Aust. 121:43-50.

Crowe LM, 2002. Lessons from nature: the role of sugars in anhydrobiosis. Comp. Biochem. Physiol. A 13:505-513.

Crowe JH, Hoekstra FA, Crowe LM, 1992. Anhydrobiosis. Annu. Rev. Physiol. 54:579-599.

Daly MJ, 2009. A new perspective on radiation resistance based on Deinococcus radiodurans. Nature Rev. Microbiol. 7:237245.

Daly MJ, Gaidamakova EK, Matrosova VY, Vasilenko A, Zhai M, Leapman RD, Lai B, Ravel B, Li S-MW, Kemner KM, Fredrickson JK, 2007. Protein oxidation implicated as the primary determinant of bacterial radioresistance. PLoS Biol. 5: e92.

Daly MJ, Gaidamakova EK, Matrosova VY, Vasilenko A, Zhai M, Venkateswaran A, Hess M, Omelchenko MV, Kostandarithes HM, Makarova KS, Wackett LP, Fredrickson JK, Ghosal D, 2004. Accumulation of Mn(II) in Deinococcus radiodurans facilitates gamma-radiation resistance. Science 306:1025-1028.

Gladyshev E, Meselson M, 2008. Extreme resistance of bdelloid rotifers to ionizing radiation. P. Natl. Acad. Sci. 105:51395144.

Guidetti R, Altiero T, Marchioro T, Sarzi Amadè L, Avdonina AM, Bertolani R, Rebecchi L, 2012. Form and function of the feeding apparatus in Eutardigrada (Tardigrada). Zoomorphology 131:127-148.

Gusev O, Nakahara Y, Vanyagina V, Malutina L, Cornette R, Sakashita T, Hamada N, Kikawada T, Kobayashi Y, Okuda T, 2010. Anhydrobiosis-associated nuclear DNA damage and repair in the sleeping chironomid: linkage with radioresistance. PLoS ONE 5:e14008.

Hengherr S, Heyer AG, Köhler H-R, Schill RO, 2008. Trehalose and anhydrobiosis in tardigrades - evidence for divergence in responses to dehydration. FEBS J. 275:281-288.

Hengherr S, Reuner A, Worland R, Brümmer F, Schill RO, 2009a. Freeze tolerance, super cooling points and ice formation: comparative studies on the subzero temperature survival of limno-terrestrial tardigrades. J. Exp. Biol. 212: 802-807. 
Hengherr S, Worland MR, Reuner A, Brümmer F, Schill RO, 2009b. High temperature tolerance in anhydrobiotic tardigrades is limited by glass transition. Physiol. Biochem. Zool. 82:749-755.

Horikawa DD, Sakashita T, Katagiri C, Watanabe M, Kikawada T, Nakahara Y, Hamada N, Wada S, Funayama T, Higashi S, Kobayashi Y, Okuda T, Kuwabara M, 2006. Radiation tolerance in the tardigrade Milnesium tardigradum. Int. J. Rad. Biol. 82:843-848.

Johansson SAE, Campbell JL, 1988. PIXE: A novel technique for elemental analysis. John Wiley \& Sons, New York.

Johansson TB, Akselsson KR, Johansson SAE, 1970. X-ray analysis: elemental trace analysis at the $10^{-12} \mathrm{~g}$ level. Nucl. Instrum. Methods 84:141-143.

Jönsson KI, 2003. Causes and consequences of excess resistance in cryptobiotic metazoans. Physiol. Biochem. Zool. 76:429435.

Jönsson KI, 2007. Tardigrades as a potential model organism in space research. Astrobiology 7:757-766.

Jönsson KI, Harms-Ringdahl M, Torudd J, 2005. Radiation tolerance in the tardigrade Richtersius coronifer. Int. J. Rad. Biol. 81:649-656.

Jönsson KI, Persson O, 2010. Trehalose in Three Species of Desiccation Tolerant Tardigrades. Open Zool J. 3:1-5.

Jönsson KI, Rabbow E, Schill R.O, Harms-Ringdahl M, Rettberg P, 2008. Tardigrades survive exposure to space in low Earth orbit. Curr. Biol. 18:R729-R731.

Kemner KM, Kelly SD, Lai B, Maser J, O’Loughlin EJ, SholtoDouglas D, Cai Z, Schneegurt MA, Kulpa Jr CF, Nealson $\mathrm{KH}, 2004$. Elemental and redox analysis of single bacterial cells by X-ray microbeam analysis. Science 306:686-687.

Makarova KS, Omelchenko MV, Gaidamakova EK, Matrosova VY, Vasilenko A, Zhai M, Lapidus A, Copeland A, Kim E, Land M, Mavromatis K, Pitluck A, Richardson PM, Detter C, Brettin T, Saunders E, Lai B, Ravel B, Kemner KM, Wolf YI, Sorokin A, Gerasimova AV, Gelfand MS, Fredrickson JK, Koonin EV, Daly MJ, 2007. Deinococcus geothermalis: the pool of extreme radiation resistance genes shrinks. PLoS ONE 9:1-21.

Mali B, Grohme MA, Förster F, Dandekar T, Schnölzer M, Reuter D, Wełnicz W, Schill RO, Frohme M, 2010. Transcriptome survey of the anhydrobiotic tardigrade Milnesium tardigradum in comparison with Hypsibius dujardini and Richtersius coronifer. BMC Genomics 11:168.

May RM, Maria M, Guimard J, 1964. [Actions différentielles des rayons x et ultraviolets sur le tardigrade Macrobiotus areolatus, à l'état actif et desséché]. [Article in French]. Bull. Biol. France Belgique 98:349-367.

Michalczyk Ł, Wełnicz W, Frohme M, Kaczmarek Ł, 2012a. Redescriptions of three Milnesium Doyère, 1840 taxa (Tardigrada: Eutardigrada: Milnesiidae), including the nominal species for the genus. Zootaxa 3154:1-20.
Michalczyk Ł, Wełnicz W, Frohme M, Kaczmarek Ł , 2012b. Corrigenda of Zootaxa, 3154: 1-20 Redescriptions of three Milnesium Doyère, 1840 taxa (Tardigrada: Eutardigrada: Milnesiidae), including the nominal species for the genus. Zootaxa 3393:66-68.

Møbjerg N, Halberg KA, Jørgensen A, Persson D, Bjørn M, Ramløv H, Kristensen RM, 2011. Survival in extreme environments - on the current knowledge of adaptations in tardigrades. Acta Physiol. 202:409-420.

Neumann S, Reuner A, Brummer F, Schill RO, 2009. DNA damage in storage cells of anhydrobiotic tardigrades. Comp. Biochem. Physiol. A 153:425-429.

Nilsson EJC, Jönsson KI, Pallon J, 2010. Tolerance to proton irradiation in the eutardigrade Richtersius coronifer: a nuclear microprobe study. Int. J. Radiat. Biol. 86:1-8.

Ramløv H, Westh P, 1992. Survival of the cryptobiotic tardigrade Adorybiotus coronifer during cooling to $-196^{\circ} \mathrm{C}$ : effect of cooling rate, trehalose level and short term preacclimation. Cryobiology 29:125-130.

Ramløv H, Westh P, 2001. Cryptobiosis in the eutardigrade Adorybiotus (Richtersius) coronifer: tolerance to alcohols, temperature and de novo protein synthesis. Zool. Anz. 240: 517-523.

Rebecchi L, Cesari M, Altiero T, Frigieri A. Guidetti R, 2009. Survival and DNA degradation in anhydrobiotic tardigrades. J. Exp. Biol. 212:4033-4039.

Reuner A, Hengherr S, Mali B, Förster F, Arndt D, Reinhardt R, Dandekar T, Frohme M, Brummer F, Schill RO, 2010. Stress response in tardigrades: differential gene expression of molecular chaperones. Cell Stress Chaperones 15:423-430.

Rizzo AM, Negroni M, Altiero T, Montorfano G, Corsetto P, Berselli P, Berra B, Guidetti R, Rebecchi L, 2010. Antioxidant defences in hydrated and desiccated states of the tardigrade Paramacrobiotus richtersi. Comp. Biochem. Physiol. B 156:115-121.

Shariff A, Bülow K, Elfman M, Kristiansson P, Malmqvist K, Pallon J, 2002. Calibration of a new chamber using GUPIX software package for PIXE analysis. Nucl. Instr. Meth. Phys. Res. B 189:131-137.

Shariff A, Kristiansson P, Auzelyte V, Elfman M, Malmqvist KG, Nilsson C, Pallon J, Wegdén M, 2004. Characterization of a new large area HPGe X-ray detector for low beam current application. Nucl. Instr. Meth. Phys. Res. B 219220:494-498.

Wełnicz W, Grohme MA, Kaczmarek Ł, Schill RO, Frohme M, 2011. Anhydrobiosis in tardigrades. The last decade. J. Ins. Physiol. 57:577-583.

Westh H, Ramløv H, 1991. Trehalose accumulation in the tardigrade Adorybiotus coronifer during anhydrobiosis. J. Exp. Zool. 258:303-311.

Wright JC, Westh P, Ramløv H, 1992. Cryptobiosis in Tardigrada. Biol. Rev. 67:1-29. 